Agata Kubala

Wrocław

\title{
A GREEK FIBULA IN THE COLLECTION OF THE ARCHAEOLOGICAL MUSEUM IN WROCŁAW
}

\begin{abstract}
In the collection of the Archaeological Museum in Wrocław is a Greek fibula, which was donated by Wilhelm Grempler, a Wroctaw doctor and researcher of antiquity well-known for his contribution to Silesian archaeology. It belongs to the 'millwheel' fibula group, which is characterised by the distinctive decoration of its bows. Fibulae of this type have been found in modern Bulgaria, Macedonia and northern and central Greece, although they seem not to have reached its south. Observable differences in the shapes of the decorative elements of these fibulae are of a regional nature and allow two varieties to be identified within the type: North Balkan and Greek. The best analogies for the Wroctaw 'millwheel' fibula can be found in objects of the same type found at Halai in central Greece, which can be dated to the mid-5th century $B C$.
\end{abstract}

Keywords: A Wroctaw fibula; 'millwheel' fibulae; Wilhelm Grempler; Archaeological Museum in Wroctaw

The Archeological Museum in Wrocław possesses a Greek fibula that is a remnant of the collection of antiquities of the former Museum Schlesischer Alterthümer in Breslau. ${ }^{1}$ The museum was founded in 1899, with one of its co-founders being Wilhelm Grempler (1826-1907), a Wrocław doctor and researcher of antiquity, who was the donor of the object under discussion

\footnotetext{
1 Before the World War II, Wrocław under the name Breslau was part of the German State. It should also be mentioned that Dr. Paweł Madera of the Archaeological Museum of Wrocław was the first to correctly describe the object as a hinge fibula. 19th century scholars considered it to be a pendant.
} 
(P1. 1). ${ }^{2}$ The beginnings of Grempler's interest in archaeology date back to 1873 , when he became a member of two German scientific societies Deutsche Gesellschaft für Anthropologie, Ethnologie und Urgeschichte and Berliner Gesellschaft für Anthropologie, Ethnologie und Urgeschichte. In the same year, he joined the Verein für das Museum Schlesischer Alterthümer and then served as its chairman from 1884 until his death in 1907. Grempler not only actively participated in international archaeological conferences, but also conducted excavations at many archeological sites, the results of which were published in 1887 and 1888 . He was also the author of numerous papers on archaeological finds from the Silesian region. All of his publications were collated into one study, which was published in 1902 (see Verzeichnis 1902). In addition, Grempler contributed to the recognition of Silesian archaeology as a specific scientific discipline dealing with the remains of the rich material culture of this historical region.

Grempler's contribution also included the donation of many ancient objects to the Museum Schlesischer Alterthümer. He had acquired a sizeable collection of antiquities as a result of the many trips he took across Africa, Asia and Europe after definitively abandoning medicine to fully devote himself to archaeology in 1890. This collection, which contained works of art of African, Asian and European provenance, was subsequently donated to the museum. Among the objects he donated were some Greek fibulae, mentioned by Hans Seger $(1899 \mathrm{a}-\mathrm{c})$ in the museum management reports from the 1895-1898 period. The first mention refers to fibulae from Kerch and Greece (Seger 1899a, 33), whilst the next records the acquisition of a valuable collection of Egyptian and Greek fibulae, alongside other ornaments (Seger 1899b, 110). It is therefore possible that the fibula now kept at the Archaeological Museum in Wrocław comes from one of these two donations. However, a third possibility also exists. The report for 1898 states that Grempler donated his collection of findings from Larissa to the museum in this year (Seger 1899c, 476). The town, located in central Greece, could also (as will be demonstrated later) very plausibly be the place of origin of the object, although the abovementioned report does not specify if the finds from Larissa included any fibulae.

Unfortunately, we do not have any information concerning either the place where the Wrocław fibula was obtained or the circumstances surrounding

\footnotetext{
${ }^{2}$ I am very grateful to Mr. Krzysztof Demidziuk from the Archaeological Museum in Wrocław for his help in uncovering information about the donor of the fibula and the circumstances of its acquisition by the museum.
} 
its acquisition. It is a very specific kind of fibula, which allows us to have a general idea of where it could have been found or acquired, based on data from the abovementioned reports and the limited area of occurrence of millwheel type fibulae. The name of the type derives from the characteristic decoration of its bow, which can be seen on the Wrocław fibula (P1. 2: 1-2). Its bow is decorated with a series of eight cylindrical projections in five groups, which create structures clearly reminiscent of a mill wheel. The two central 'millwheels' have one of their projections broken off. On both sides of the 'millwheels', rings with short parallel lines are incised. The hinge plate takes the form of a five-petal palmette emerging from a double volute. The catch of the needle is decorated with two hollow balls, flattened at the back, which are placed on either side of it. The needle itself has not been preserved. The fibula is made of silver, its length is $3.3 \mathrm{~cm}$ and its height at the highest point of the bow is $2.4 \mathrm{~cm}$.

Fibulae of the millwheel type have almost exclusively been found in the Balkans, specifically in present-day Bulgaria (Filow and Welkow 1930, 309, fig. 30; Venedikov and Gerasimov 1975, figs. 210-212), Macedonia (Cassirer and Helbing 1928, pl. VII; Popovič 1956, 104f., pl. XI) and northern and central Greece (Marshall 1911, 335, pl. LXVII, nos. 2841-2844; Walker and Goldman 1915, 425, fig. 2; Amandry 1963, 203, fig. 109 left). The find locations indicate that this type of fibula was in use within a limited area throughout which it seems to have been produced during the same period. The only information concerning millwheel type fibulae found beyond the area outlined above comes from the catalogue of Greek, Etruscan, and Roman jewellery in the collection of the British Museum, published in 1911 (Marshall 1911). In this publication, two fibulae are said to have been found in a tomb at Elis in the Peloponnese in western Greece (Marshall 1911, 335, pl. LXVII, nos. 2845-2846). The small number of finds of millwheel type fibulae in the territories of northern and central Greece may further indicate that these pins, described by some scholars as typically northern Greek (von Bothmer and Mertens 1982, 18), were not in fact of great popularity in this region. Archaeological evidence indicates that these fibulae were produced from at least the mid-5th to the end of the 4th century BC. The oldest objects of this type, found at Halai in central Greece, may be dated to the mid-5th century BC. ${ }^{3}$ A. Oliver Jr. $(1966,272)$ stated that the end of the 6th century was the time when the first millwheel type fibulae

\footnotetext{
3 These fibulae have not been worked on so far. I received information on their dating from Dr. George Kavvadias, Head of the Department of Vases, Minor Arts and Metalwork of the National Archaeological Museum of Athens.
} 
appeared, probably based on older proposals of the dating of fibulae found at Trebenishte in Macedonia (see Vulić 1932, 1) by L. Popovič $(1956,86)$. It seems more likely, however, that the second half of the 5th century BC is the correct period. The latest known objects of this characteristic type can be dated to 330-300 BC. They form part of a set of ancient ornaments, known as 'The Ganymede Jewelry', which was found near modern Thessaloniki (Richter 1931, 290f., fig. 2). Taken together, the preserved examples, which date to different periods within the time of the fibula's use, indicate that the millwheel type remained fairly uniform throughout the entire duration of its production. The differences that may be observed mainly concern the shape of the projections forming the 'millwheels' that decorated the bows. It seems that their form depended on the area of production. Projections of fibulae produced in ancient Greece are cylindrically-shaped, straight or slightly narrower towards the top (Walker and Goldman 1915, fig. 2), while projections of 'millwheel' decorated fibulae made in ancient Macedonia are shorter, wider and strongly flattened, causing them to more closely resemble the petals of a flower (see Richter 1931, fig. 2; Popovič 1956, pl. XI; Amandry 1963, fig. 109 left). Additionally, in some cases, the hinge plates take the form of rectangular boxes decorated with a relief (see Richter 1931, figs. 2 and 5). The bows of the fibulae found in Bulgaria are embellished with flanges consisting of short, flattened and pointed projections, whereas their hinge plates are in the shape of a triangle with rounded corners and beaded edges. Their surfaces are decorated with engraved palmettes (Filow and Welkow 1930, 309, fig. 30).

The object under discussion is most similar to the millwheel type fibulae found during the American excavations at Halai of Locris in central Greece carried out in the years $1911-1914 .{ }^{4}$ According to the information provided by A. L. Walker and H. Goldman $(1915,426)$, who led the excavations at Halai, the fibulae, like other jewellery from the site, were found in graves. However, in their report published in 1915 (Walker and Goldman 1915), no information is given on when the graves and the fibulae themselves date back to. A stylistic analysis of the fibulae from Halai (which have not yet received the attention they are due) demonstrates their obvious similarity to the Wrocław pin; this is particularly visible in the case of the largest objects in the set, which consist of 14 silver fibulae of different sizes

\footnotetext{
4 They are now kept in the National Archaeological Museum of Athens, collective inv. no. X $\rho .981$. This information was received from Dr. G. Kavvadias, to whom I am very grateful for his assistance.
} 
(P1. 3). ${ }^{5}$ The projections forming 'millwheels' are almost identically shaped and they take the form of cylinders rounded at the top. Strong similarities are also observable in the shape of the hinge plates, which are formed by five-petal palmettes rooted in double volutes. The smaller objects in the set from Halai have similarly shaped projections, but are shorter and distinctly narrower towards the top and the palmettes forming their hinge plates consist of more petals, which are long and slender. Another similarity between the Wrocław fibula and objects of the same type from Halai is the shape of the catch accompanied by two hollow balls. However, it should be stressed that both the shape and the ornamentation of the catch is typical for all known fibulae of the millwheel type regardless of the place in which they were found. Almost identically shaped and decorated catches may be seen on fibulae found in Thessaly, which in ancient times was a part of northern Greece (Marshall 1911, pl. LXVII, nos. 2841-2844), as well as on pins found in the territory of the ancient Macedonian kingdom (Richter 1931, fig. 2; Vulić 1932, fig. 20). Catches of the same shape also occur on millwheel type fibulae from Bulgaria (Filow and Welkow 1930, fig. 30).

The analysis above clearly shows that the fibula kept at present in the Archaeological Museum in Wrocław was very probably made in central Greece and that it is an example of a very recognisable type of fibulae, known as 'millwheel' for its unique bow ornamentation. Differences within the type, mainly noticeable in the decoration, seem to be regional. Northern Balkan fibulae are characterized by 'millwheels' consisting of strongly flattened projections, whereas the protrusions of 'millwheels' decorating bows of fibulae produced in ancient Greece are round. As indicated above, observable differences in the shape of the hinge plates may also be considered regional variations.

The millwheel type fibulae found in a grave in Elis in western Greece are very similar to the Northern Balkan variant of the type (Marshall 1911, pl. LXVII, nos. 2845-2846). However, it seems that they were not produced locally and that they reached Elis as imports. This was perhaps from the area of Macedonia, since they show a striking similarity to objects of the same type found at Trebenishte (see Vulić 1932, fig. 25).

The closest analogies to the object in question can be found in fibulae of the millwheel type found at Halai, which date back to the mid-5th century BC. It is therefore very likely that the Wrocław fibula was made

\footnotetext{
${ }^{5}$ In the picture presented here as Pl. 3: 13, some fibulae can be seen. However, Dr. G. Kavvadias has informed me, that a total of seven pairs of silver fibulae from the American excavations at Halai are kept there.
} 
at approximately the same time, which would thus make it one of the oldest known objects of the type discovered so far. In addition, it does not differ from the examples cited above in terms of the material used to make it. Silver was the metal most frequently used for the production of millwheel type fibulae, regardless of the time and place in which they were made (Olivier Jr. 1966, 272), and almost all of the examples cited above are made of this metal. The only exceptions are the millwheel type fibulae from the set called 'The Ganymede Jewelry', which are made of gold (Richter 1931, 290). The shape and decoration of the Wrocław fibula, as well as the material it is made of, clearly confirms its place within a very interesting class of fibulae named after its unique bow ornamentation, a class which has not yet received the attention it is due. Northern Balkan finds of such fibulae show that they may have been paired with a braided chain, sometimes decorated with pendants, which further emphasised their decorative nature (see Filow and Welkow 1930, fig. 30). They seem to have served as decorative rather than utilitarian objects and were probably used as modern brooches are today.

It is neither possible to determine which of the donations mentioned above was the source of the fibula under discussion, nor how it came into the hands of its donor, Wilhelm Grempler. It is also not possible to establish if it was purchased or found during fieldwork. However, it is very likely that the place of its acquisition was Larissa (the largest city of Thessaly, which in ancient times was a very important metropolis in northern Greece) or its surroundings and that it was donated to the former Museum Schlesischer Alterthümer as part of a set of ancient objects described in a report of Seger (1899c, 476), which were found at this Greek city. If the Wrocław fibula formed part of one of two earlier donations (see above), the place of its production must have been a centre located either in northern or central Greece. 


\section{References}

Amandry P. 1963. Collection Helene Stathatos. Vol. 3: Objects Antiques et Byzantins. Strasbourg.

Bothmer D. von and Martens J. R. 1982. The Search for Alexander. Supplement to the Catalogue. New York: the Metropolitan Museum of Art.

Cassirer P. and Helbing H. 1928. Sale Catalogue of the Gans Collection. Berlin.

Filow B. and Welkow I. 1930. Grabhügelfunde aus Duvanlii in Südbulgarien. JdI 45, 281-322.

Marshall F. H. 1911. Catalogue of the Greek, Etruscan, and Roman Jewellery in the Department of Antiquities, British Museum. London.

Olivier Jr. A. 1966. Greek, Roman, and Etruscan Jewelry. The Metropolitan Museum of Art Bulletin 24/9, 269-284.

Richter G. M. A. 1931. The Ganymede Jewelry. The Metropolitan Museum of Art Bulletin 32, 290-295.

Popovič L. 1956. Katalog nalaza iz nekropole kod Trebeništa. Beograd.

Seger H. 1899a. Verwaltungsbericht für das Jahr 1895. Schlesiens Vorzeit in Bild und Schrift 7, 26-40.

Seger H. 1899b. Verwaltungsbericht für das Jahr 1896. Schlesiens Vorzeit in Bild und Schrift 7, 101-122.

Seger H. 1899c. Verwaltungsbericht für das Jahr 1898. Schlesiens Vorzeit in Bild und Schrift 7, 465-480.

Venedikov L. and Gerasimov T. 1975. Thracian Art Treasures. Sofia, London.

Verzeichnis 1902. Verzeichnis der Prähistorischen Schriften von Wilhelm Grempler zum fünfzigjährigen Doktorjubiläum des Verfassersdar geb-racht vom Vereinfür das Museum Schlesischer Alterthümer. Breslau.

Vulić N. 1932. Ein neues Grab bei Trebenischte. Jahreshefte des Öster-reichischen Archäologischen Institutes in Wien 27, 1-42.

Walker A. L. and Goldman H. 1915. Report on Excavations at Halae of Locris. AJA 19, 418-437.

Agata Kubala Institute of Art History University of Wrocław agatak0@op.p1 


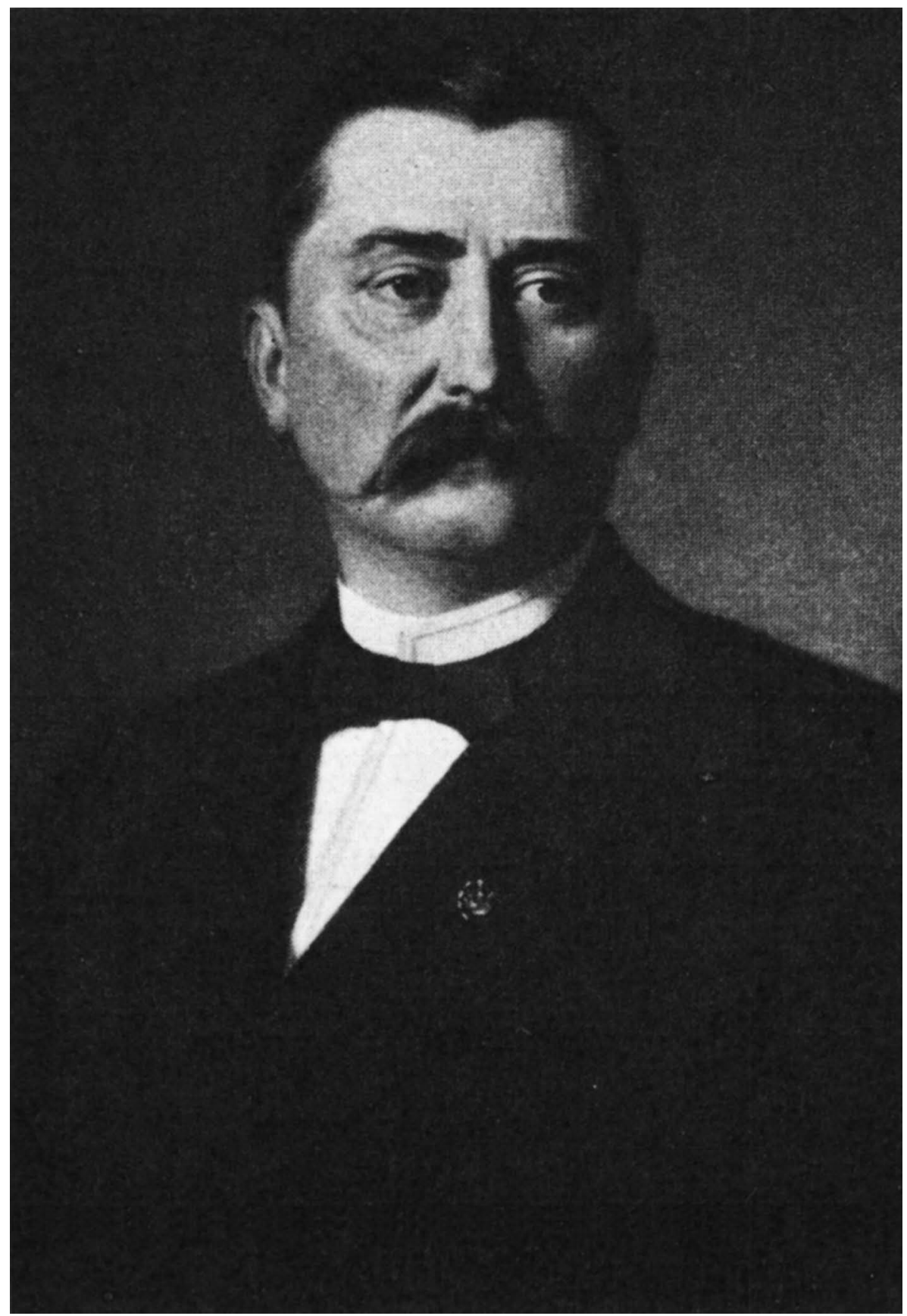

P1. 1. Wilhelm Grempler.

Photographic Archive of the Archaeological Museum in Wrocław 

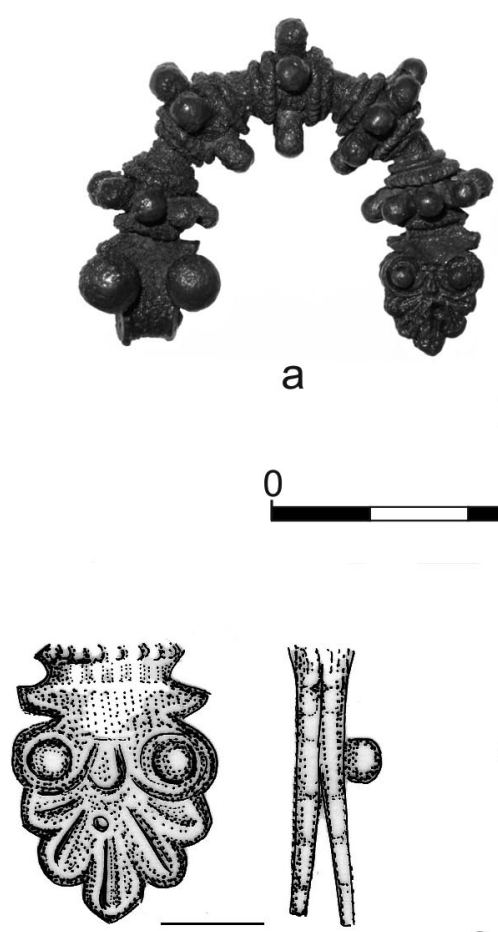

a

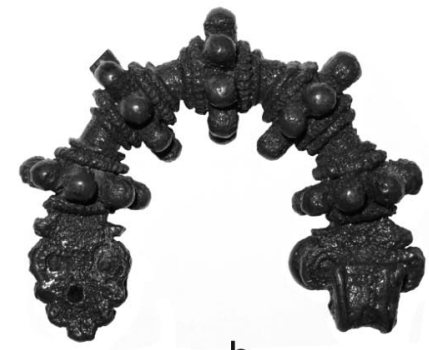

b

1

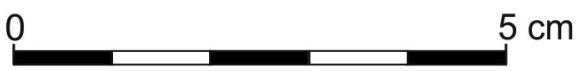

Pl. 2. Fibula of the millwheel type, silver, length $3.3 \mathrm{~cm}$, inv. no. MNW/A/III/2601, mid-5th century BC(?). Courtesy of the Archaeological Museum in Wrocław. 1 - View of the upper side and the underside 2 - Drawing by Teresa Demidziuk 

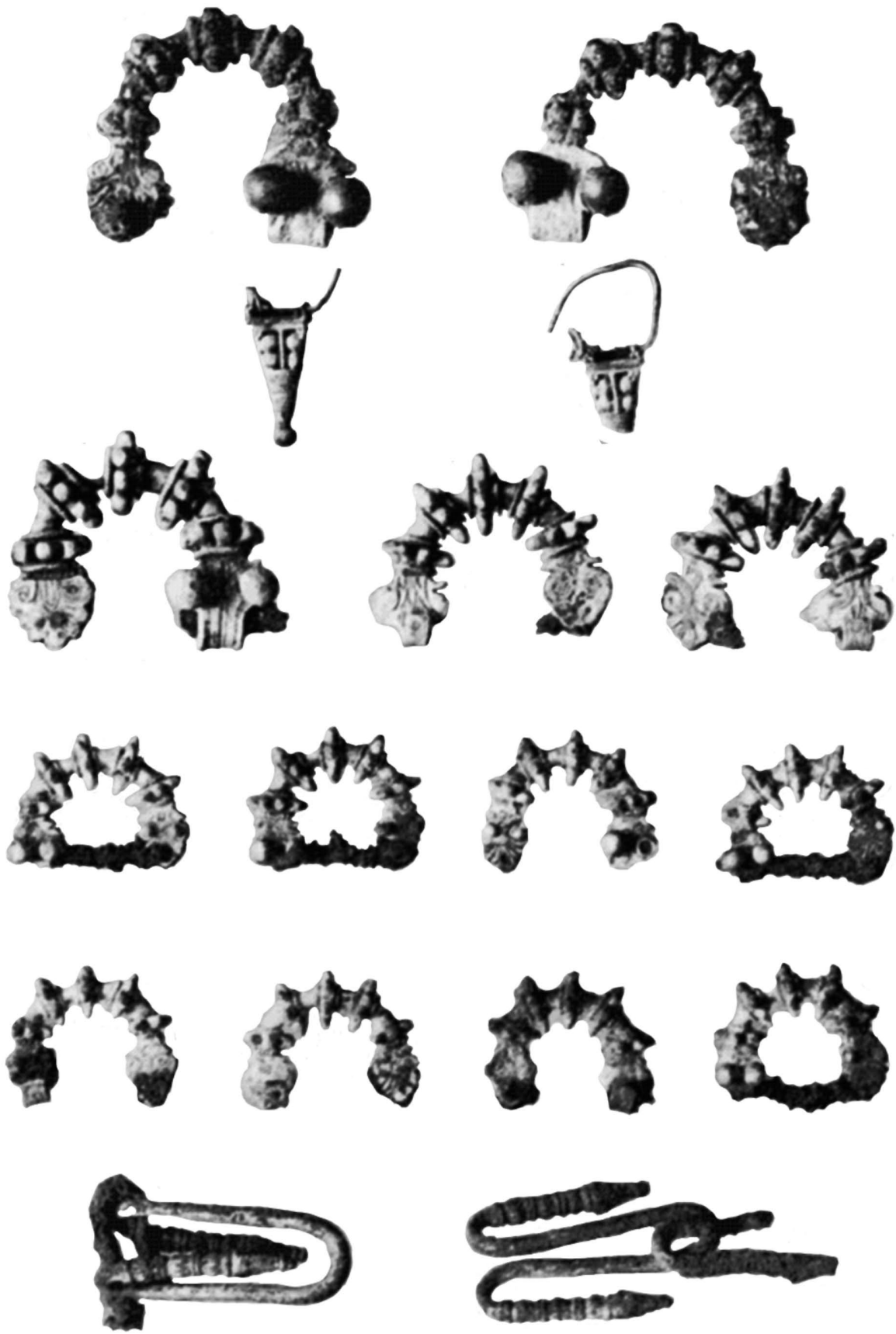

P1. 3. Fibulae of the millwheel type found at Halai.

Reproduced from Walker and Goldman 1915, fig. 2 